\title{
LITTÉRATURE
}

ALICJA BACZYK-TOMASZEWSKA

Universidad Adam Mickiewicz, Poznań

\section{EL TEMA DE LA SOLEDAD EN GÓNGORA, GUSTAVO GARCÍA SARAVÍ Y JUAN GOYTISOLO}

A b st r a c t. Baczyk-Tomaszewska Alicja, El tema de la soledad en Góngora, Gustavo García Saraví y Juan Goytisolo [The subject of solitude in Góngora, Gustavo García Saraví and Juan Goytisolo]. Studia Romanica Posnaniensia, Adam Mickiewicz University Press, Poznań, vol. XXIX: 2003, pp. 3-9. ISBN 83-232-1232-5, ISSN 0137-2475.

The aim of this article is to compare two representatives of modern Spanish literature with the Baroque poet, Góngora. Góngora's distinct influence on the poetry of an Argentinian poet, Gustavo García Saraví and the Spanish prose writer, Juan Goytisolo on the level of content and form may be observed. The author also considers the problem of human fate, marked with suffering and loneliness, which is described by all the three authors from the perspective of a pilgrim.

Cuando estudiamos los textos de Gustavo García Saraví y Juan Goytisolo experimentamos la presencia en ellos de Góngora, el poeta español barroco. Dicha presencia se nota sobre todo en un especial culto a la palabra que profetizan los dos representantes de la lengua española. El poeta platense compuso sonetos, la forma más perfecta de poesía, y el verso libre tampoco le era ajeno. El escritor castellano escribió artículos del carácter del ensayo que fueron agrupados por él en el libro titulado Aproximaciones a Gaudí en Capadocia y novelas. Aquí estudiaremos una de sus novelas escritas en la época de su rechazo de la escritura tradicional.

Planteo la tesis de que el lazo de unión entre los tres representantes de la lengua española es la recurrencia al tema de la soledad.

El título del conjunto de poesías de Góngora es el de Soledades. Es allí donde el poeta describe el campo comparándolo al espacio de la ciudad y la naturaleza a la arquitectura. El poeta llega al campo como peregrino. Es el caso del viajero gongorino y también de ese de Juan Goytisolo. Aquí hay que hacer una observación sobre el sentido de la palabra peregrino. Pues, peregrino como adjetivo „se aplica al que anda por tierras extrañas". Y que sentido tienen esas tierras extrañas? 
Parece que la mejor explicación es la de tierras extranjeras o raras ${ }^{1}$. El narrador de Aproximaciones a Gaudi en Capadocia visita la región turca tomando aires del viajero barcelonés el cual reconoce en la estructura del terreno las formas arquitectónicas del celebre arquitecto de Barcelona. Entonces ocurre que el narrador se desplaza mentalmente a Barcelona, al Paseig de Gracia, donde están la Casa Milá y la Pedrera, visita también el Parque Güell y el templo expiatorio de la Sagrada Familia. De esta manera el narrador realiza una peregrinación por el espacio y por el tiempo. La naturaleza parece solidaria con el sentimiento del narrador que contempla la belleza del terreno que le parece irreal. Es el ambiente del misterio místico parecido al que reina en los templos expiatorios de la Edad Media, la obscuridad del interior y la luz que se esfumina por las vidrieras. La frase de Gaudí citada por Goytisolo en ese artículo: La Glòria és la llum (Aproximaciones a Gaudí en Capadocia, p.17) parece ser lema del dicho texto poniendo en relieve el aspecto espiritual de la luz. Es el destino del peregrino a que este aspira - acceder al estado de iluminación por vía de purificación. Ya no se sentirá solo, será acompañado por la presencia de lo divino.

El sujeto lírico del soneto de García Saraví monta a caballo para llegar a la pampa. La extensión del espacio le llena de melancolía y le hace pensar en su soledad:

La soledad me trepa por el tallo

y mi raíz es soledad quemante.

Estoy solo hacia atrás y hacia adelante

y así crezco en penurias y batallo. (El ombú, en: La patria adentro, p.142)

Se trata de la batalla de Manuel León Barreto a quien dedica este soneto el poeta platense. El soneto entero es un grito de soledad de ese hombre que se siente en la pampa solo como el ombú, el arbusto típico de la pampa:

Me enfrento solo contra el sol y el rayo,

contra la pampa bárbara, abrasante.

El hombre siente la falta de sentido de su vida:

Soy humo inmóvil, verde, desafiante,

cien ramas para arriba y un caballo.

Hay que hacer una observación: la comparación del hombre al humo es muy gongorina. Tiene carácter existencial y señala el paso del tiempo y la banalidad de la vida. A la sencillez de imágenes corresponde en Góngora la complejidad del lenguaje. El mismo fenómeno lo observamos en García Saraví y Goytisolo. Es que el lector debe descifrar el misterio de la palabra. Es característico el uso de las palabras de orígen extranjero, griego, en Góngora y Goytisolo, persa en Saraví. Así

\footnotetext{
${ }^{1}$ El pequeño Espasa, Espasa-Calpe, Madrid 1989.
} 
la palabra de origen latino can está empleada por el poeta barroco para decir el perro (Soledad primera, verso 84, p.79)

Cuando el escritor castellano habla de Gaudí quien se había refugió en Capadocia para continuar su creación, emplea la palabra anacoreta. (Aproximaciones a Gaudí en Capadocia, p. 11) Ésta lleva el sentido de una „persona que vive en lugar solitario, entregada a la contemplación y a la penitencia", Esta vuelta al origen de la palabra coincide con el retorno del hombre a la naturaleza que profetizaba el arquitecto catalán. El poeta platense emplea palabras de orígen persa para embellecer la forma de su soneto, otorgarle un ambiente de lo exótico, por ejemplo en él titulado La calesita la palabra caravana. El lector debe escoger entre dos sentidos de esta palabra, sea él de ,grupo de gentes en Asia y África que se juntan para hacer un viaje con seguridad" sea él de „conjunto de vehículos que, por ser la circulación muy densa o por otras razones, van uno detrás de otro y poco distanciados entre $\mathbf{s i}^{\prime 3}$. Tomando en cuenta que el tema del soneto es el tiovivo, podemos optar por la segunda explicación de la palabra, entonces daríamos importancia al aspecto técnico de la palabra - el conjunto de vehículos, no obstante la primera explicación que significa "el conjunto de gentes" subraya el elemento humano. El poeta compara la escritura al círculo que hace el tiovivo y dice que ella debe ser concéntrica, es decir tiene que girar alrededor del tema escogido. La alusión a la infancia sugiere la idea de la espontaneidad y naturalidad del verso que el poeta quiere radiante y mágico, es decir bello y misterioso.

La calesita

Grillo redondo y musical, reverso de la quietud, la recta y la premura, ilusión circular que transfigura la mano cruel y el porvenir perverso.

Borriquillo con duendes, universo de toda infinitud en miniatura, esplendor de la risa y la ventura de hacer poemas con un solo verso.

Guardapolvo de mimbres y madera para vestir la infancia, la primera mano dorada que nos corresponde,

caravana concéntrica, radiante atrás jovial y mágico adelante sin desde cuándo ni por qué ni a dónde.

(Del amor y los otros desconsuelos, en: Obras completas, p. 187).

\footnotetext{
${ }^{2}$ Ibidem.

${ }^{3}$ Ibidem.
} 
El giramiento del tiovivo al cual compara Saraví la escritura recuerda la danza de los místicos de Konya. Los sufí efectúan una danza sin fin que hace pensar en „la ronda vertiginosa y perpetua de los nueve astros", como la define Juan Goytisolo. El escritor castellano dice ${ }^{4}$ :

¡Oh día, ven, los átomos danzan!

¡Las almas sumidas en éxtasis danzan!

Al oído te diré adónde lleva la sama.

Todos los átomos del aire y desierto,

entérate bien, parecen insensatos.

Cada âtomo, miserable o feliz,

se enamora del sol, en verdad inexpresable.

La escritura de un verso parece un verdadero „camino de perfección”, una búsqueda contínua de palabras convenientes y rimas adecuadas. Para llegar a ello el artista necesita recogimiento y soledad fecunda. Solamente en ese ambiente puede encontrar unas sonoridades adecuadas al contexto; ello se realiza gracias a la selección de sustantivos que indican nombres de instrumentos acompañados por los adjetivos que subrayan la potencia del efecto sonoro, por ejemplo: la trompa militar, la sonora pluma (Góngora, Soledad primera). Esta última es alusión a la escritura. La influencia gongorina la acabamos de observar en el soneto de García Saraví donde el poeta utiliza las sugerencias musicales provocadas por el grillo redondo y musical.

Existe un bello soneto escrito por García Saraví donde el poeta habla de sus frustraciones que vive mientras compone el poema:

Esa inutilidad, esta madeja

de nebulosas tintas, este miedo

de conceder, al fin, lo que concedo

a la hermosa palabra que refleja,

solamente, el reflejo que me deja

la íntima palabra que no puedo

expresar, este ovillo donde quedo

enredado en la lástima, esta reja

de vocales y símbolos que engrilla

con sonoras durezas la sencilla

complicación de ser el otro lado

de mí mismo, mi página más pura,

se llama aún poema, una impostura,

un niño muerto, un fuego congelado.

(De la frustración y el engaño de las palabras y el soneto, en: Del amor y otros desconsuelos, pags. 184-185).

\footnotetext{
${ }^{4}$ Los derviches giróvagos, en: Aproximaciones a Gaudí en Capadocia, p. 35.
} 
En el soneto que acabo citar aparece también otro interesante recurso estilístico: la repetición de palabras: el sustantivo reflejo y el verbo reflejar. La repetición significa que el poeta no puede realizar el hecho del que está hablando: el reflejo o sea la representación de la palabra.

En Góngora observamos el lenguaje metafórico, así las fieras son imagen del instinto. En García Saraví la imagen del toro simboliza la vitalidad y también la soledad del animal cuyo destino irrevocable es la muerte.

El peregrinaje está marcado por la búsqueda de la casa. El peregrino gongorino encuentra el albergue en una choza hecha de hojas secas (Soledad primera, v.175). El poeta barroco presenta dicha choza bajo la forma arquitectónica del obelisco y dice: „el verde obelisco de la choza”. Tenemos que analizar el color y la forma. El color está sugerido por medio de la alusión a las hojas. La choza debe de ser hecha por las hojas de un árbol y al mismo tiempo su forma parece al obelisco. Dicha forma del obelisco indica ,el pilar muy alto terminado por una punta piramidal muy achatada, el cual sirve de adorno en los lugares públicos, y lo emplearon principalmente los egipcios cubierto de inscripciones jeroglíficas", Hay en esa explicación varios elementos significantes, el primero, es la forma vertical que tiene, el pilar y como tal puede ser tratado como símbolo de unión del cielo y la tierra $^{6}$ y el eje del mundo. Se trata pués de una casa, un albergue particular que constituye un centro del mundo. Volver al centro del mundo, significa volver a la matriz, al comienzo de la vida, al seno materno. Góngora evoca en sus Soledades tales imágenes del retorno al estado natural de vida para consolarse de las atrocidades de su vida en la corte donde no se siente a su gusto.

Otro elemento es la evocación de los tiempos pasados, en ese caso de los del Egipto. La palabra 'obelisco' parece sugerir la vieja cultura de los faraones que eran ricos y construían bellas casas que adornaban bellamente. El albergue que encuentra el peregrino gongorino no es pués una casa cualquiera, pero la que tiene valor de algo rebuscado y bello. De este modo se manifiesta el lenguaje barroco de Góngora en el cual la ilusión lleva un papel importante. La choza que encuentra el peregrino en el bosque parece un obelisco en los ojos de ese viajero deseoso de descansar después de su paseo por el bosque. El poeta se sirve del arte de ilusión barroca como manera de engañar al lector. La palabra ilusión tiene su origen en el latin, ilusio, -onis, que significa el 'engaño' y es un derivado de illudere 'engañar'?

Hemos dicho que el campo en los sonetos del poeta platense aparece bajo la imagen de la pampa. La pampa significa para Saraví la soledad pero también la libertad. Es lo que falta a la ciudad: los nombres de las calles facilitan el desplazamiento, pero todas llevan al cementerio donde yace un poco del poeta, allí

\footnotetext{
${ }^{5}$ Definición del diccionario: El pequeño Espasa, op.cit.

${ }^{6}$ M. E l i a d e, Szamanizm i archaiczne techniki ekstazy, PWN, Warszawa 1994.

${ }^{7} \mathrm{~J}$. C o rom in as, Breve diccionario etimológico de la lengua castellana, tercera edición,
} Gredos, Madrid 1983. 
se encuentra la tumba de la madre del poeta. Igualmente en Goytisolo: desde el monte Montjuîc de cuya altura Álvaro, el personaje principal de Señas de identidad, observa el panorama de Barcelona, se puede llegar al cementerio. Es aquí donde yace la madre del escritor. Las calles de las ciludades mediterráneas que describe el escritor castellano son llenas de violencia y agresión. El símbolo del malo que reina en la ciudad es el gato destrozado en la calle de Cairo. El movimiento de las calles está presentado bajo imágenes de la masa humana que se mueve según el orden militar:

(...) la marea humana lanzada al asalto de autóbuses, el ejército peatonal enfrentado a la barahúnda y zurrido de los motores, el hormigueo incesante de todo un pueblo que, con eficaz economía de movimientos, aprovecha la exigüidad del espacio concendido a los cuerpos para correr afanosamente a los puntos de reposo o actividad habituales, calculando tal vez como el desvalido animal, a través de telarañas y sombras, la próroga avariciosa que dispone, el lapso otorgado por el destino a su precaria existencia en una aglomeración en la que han desaparecido las aceras, el suelo está lleno de socavones, los automovilistas no respetan las luces ni el silbato de los policías, una megalópolis cruel para inválidos y ancianos, ciudad sin misericordia, señor (...) ( La ciudad de los muertos, en: Aproximaciones a Gaudí en Capadocia, p. 63-64)

Esas imágenes impresionistas de las calles modernas („el hormigueo incesante de todo un pueblo") subrayan la falta de comunicación humana, el cruel destino de gente débil perdida en el gran espacio ciudadano. El uso del sustantivo megalópolis para hablar de la gran aglomeración urbana sugiere el otro: megalomania, y éste significa la manía de grandeza. De ese modo la ciudad recibe el aspecto despectivo.

El rechazo de la ciudad por parte de los tres artistas está motivado por la crítica de la sociedad siempre presente en sus textos. Góngora critica la corte y la aristocracia, García Saraví y Juan Goytisolo - la burguesía. García Saraví opina que la sociedad es seno de la soledad. A las familias les falta unión, ya no garantizan valores seguros a las futuras generaciones:

Los padres separados

y las joviales divorciadas

pasean los domingos con sus hijos.

( $\mathrm{Y}$ algunas fiestas de guardar)

Van a Palermo, a parques

de diversiones poco divertidos,

a cines suburbanos donde exiben películas

obscenas para niños a al Zoológico,

en el que mueren diariamente

las últimas jirafas y osos panda del mundo.

[Domingo, en: Libro de quejas, pags. 215-216].

La soledad es parte de la condición humana. A esta conclusión llega el poeta cuando se da cuenta de que el número de sus amigos disminuye. La soledad es una 
de las cosas irreparables en ese mundo y su dimensión puede ser comparada a la del hambre de los niños:

En nuestro tiempo hay varias cosas

irreparables:

la soledad, los barbitúricos,

el psicoanálisis,

el hambre de los niños,

la ponderable bomba de cobalto.

(Fotografía del siglo XX y principios del XXI, en: Libro de quejas, p. 218).

\section{BIBLIOGRAFIA}

Corominas, J. (1983), Breve diccionario etimológico de la lengua castellana, tercera edición, Gredos, Madrid.

E 1 i a d e, M. (1994), Szamanizm i archaiczne techniki ekstazy, PWN, Warszawa, trad. del francês por Kocjan K., Le chamanisme et les techniques archaïues de l'extase, 1951, Payot, París 1968.

G ó n g o r a, L. (1989), Soledades, edición de John Beverley, Cátedra, Madrid.

G o y t i s o l o, J. (1979), Señas de identidad, Editorial Argos Vergara, Barcelona.

- (1990), Aproximaciones a Gaudí en Capadocia, Mondadori España S. A., Madrid.

Gar cia S a raví, G. (1981), Obras completas, edición de Sara M. Parkinson de Saz, Editorial Empeño 14, Madrid. 